\title{
COMBAT ARMY SYSTEM - AS A MEANS OF INCREASING AND IMPROVING THE PHYSICAL FITNESS OF SERVICEMEN OF THE ARMED FORCES
}

\author{
Volodymyr Klymovych' \\ https://orcid.org/0000-0003-4678-5002 \\ Artur Oderov ${ }^{2}$ \\ https://orcid.org/0000-0002-7791-0825 \\ Serhii Romanchuk ${ }^{3}$ \\ https://orcid.org/0000-0002-2246-6587 \\ Antonina Dunets-Lesko 4 \\ https://orcid.org/0000-0002-0512-7989
}

\author{
Tetiana Liudovyk ${ }^{5}$ \\ https://orcid.org/0000-0002-2407-0447 \\ Vasyl Lishchuk ${ }^{6}$ \\ https://orcid.org/0000-0002-4362-7263 \\ Andriy Baldetskiy ${ }^{7}$ \\ https://orcid.org/0000-0001-6979-066X
}

\begin{abstract}
${ }^{1-3,5}$ National Army Academy named after Hetman Petro Sahaidachnyi, Lviv, Ukraine
${ }^{4}$ Lviv State University of Physical Culture named after Ivan Boberskij, Lviv, Ukraine

${ }^{6}$ Kamianets-Podilskyi Ivan Ohiienko National University, Kamianets-Podilskyi, Ukraine

${ }^{7}$ Military Institute of Taras Shevchenko National University of Kyiv, Kyiv, Ukraine
\end{abstract}

Given the peculiarities of the participation of units in peacekeeping operations and the experience of combat operations, the psychological resilience of servicemen and the professional competence of officers are becoming increasingly important, in the formation of which special physical training plays an important role.

The analysis of the improvement of combat operations by means of physical training shows that most military specializations require an increased level of requirements that are set and required by the physical training of servicemen. Given the short period of service in the military requires, in turn, training in military institutions with the alternate introduction and improvement of physical education, as the main component of combat training of servicemen of the Armed Forces. Provision of modern weapons and military equipment of the Armed Forces of Ukraine, participation of servicemen in combat operations, improvement of combat training of personnel, education of confidence and determination during combat missions, the need to maintain at the appropriate level and in constant combat readiness of units of Ukraine need constant improvement and professional development of personnel.

Exercises that are performed during the performance of tasks for a long time, as well as any activity of servicemen, in the end must bring a positive result, with a goal to achieve a specific goal. Therefore, the theory of transfer and performance of physical exercises during practical classes must ensure high-quality performance of tasks as intended during combat. Therefore, the purpose of our study is to conduct a detailed analysis of the tasks of servicemen of the Armed Forces of Ukraine and the Armed Forces of leading NATO countries and the introduction of a high-quality and effective system of physical training, which will further ensure special and combat tasks methods of organizing the organization of physical training and will ensure the creation of a unified system of tactical and melee training for the Armed Forces of Ukraine. Material: Conceptual use in the educational process of professionally oriented physical training in the Combat Army system involves the formation of servicemen's military-applied motor skills, physical and moral qualities to perform tasks as assigned. The article describes and analyzes the impact of the Combat Army system as a training system that fully provides quality training of servicemen to perform combat missions on purpose in modern conditions. Results: Our study revealed a positive effect of special physical training (BARS) on the level of development of physical qualities. Given the constant increase in the requirements for the level of professional training of personnel of the Armed Forces of Ukraine, the need to ensure the physical readiness of servicemen for combat activities and physical training of units, physical education specialists should take measures to rationally use time during training sessions with personnel. In the future, our research is planned to focus on determining the impact of special physical training (BARS) on the level of development of professionally important (special) physical qualities of cadets of different specialties.

Key words: military-applied training, physical fitness, structure, battle, Armed Forces, serviceman, combat training.
Володимир Климович, Артур Одеров, Сергій Романчук, Антоніна Дунець-Лесько, Тетяна Людовік, Василь Ліщук, Андрій Балдецький. Бойова армійська система як засіб підвищення фізичної підготовленості військовослужбовців Збройних Сил

Анотація. Враховуючи особливості участі підрозділів у миротворчих операціях та досвід бойових дій, психологічна стійкість військовослужбовців та професійна компетентність офіцерів набувають все більшого значення, у формуванні яких важливу роль відіграє спеціальна фізична підготовка. Аналіз вдосконалення бойових дій засобами фізичної підготовки показує, що більшість військових спеціалізацій вимагають підвищення рівня вимог, які висуваються та вимагаються фізичною підготовкою військовослужбовців. Враховуючи короткий термін служби у війську, у свою чергу вимагає навчання у військових закладах з почерговим впровадженням та вдосконаленням фізичного виховання як основного компонента бойової підготовки військовослужбовців Збройних Сил. Забезпечення сучасним озброєнням та військовою технікою Збройних Сил України, участь військовослужбовців у бойових діях, вдосконалення бойової підготовки особового складу, виховання впевненості та рішучості під час виконання бойових завдань, необхідність підтримки на належному рівні та у постійній бойовій готовності одиниць України потребують постійного вдосконалення та підвищення кваліфікації персоналу.

Вправи, які виконуються під час виконання завдань протягом тривалого часу, а також будь-яка діяльність військовослужбовців врешті-решт повинні принести позитивний результат з метою досягнення певної мети. Тому теорія передачі та виконання фізичних вправ під час практичних занять повинна забезпечувати якісне виконання завдань, передбачених під час бою. Тому мета нашого дослідження провести детальний аналіз завдань військовослужбовців Збройних Сил України та 3бройних Сил провідних країн НАТО, впровадження якісної та ефективної системи фізичної підготовки, що надалі забезпечить вирішення спеціальних і бойових завдань методами організації фізичної підготовки та створення єдиної системи тактичної, рукопашної підготовки для Збройних Сил України. Матеріал і методи.

Результати: Проведене нами дослідження виявило позитивний вплив засобів спеціальної фізичної підготовки (БАрС) на рівень розвитку фізичних якостей. Враховуючи постійне підвищення вимог до рівня професійної підготовленості особового складу Збройних Сил України, необхідності забезпечити фізичну готовність військовослужбовців до бойової діяльності і фізичну підготовку підрозділів, фахівці фізичного виховання повинні вживати заходи щодо раціонального використання часу під час проведення навчально-тренувальних занять з особовим складом. В подальшому наші дослідження планується зосередити на визначення впливу засобів спеціальної фізичної підготовки на рівень розвитку професійно важливих (спеціальних) фізичних якостей курсантів різних спеціальностей.

Ключові слова: військово-прикладна підготовка, фізична підготовленість, будова, бій, Збройні сили, військовослужбовець, бойова підготовка. 


\section{Introduction}

Combat tasks for the current purpose, which will be performed by servicemen of the Armed Forces of Ukraine, require and require significant psychological stability and appropriate physical activity, according to the position held (Klymovych, Korchagin, Olkhovyi, Romanchuk \& Oderov, 2019).

Factors that have a significant impact on the conduct of hostilities by military personnel require them to be in constant physical shape for high-quality and timely fulfillment of the assigned tasks, as well as for the development of a high level of physical and moral development of volitional qualities and physical health. Therefore, having military skills and ability allows a soldier to use conventional weapons, while being of vital importance (Klymovych, Oderov, Korchagin, Olkhovyi \& Romanchuk, 2019; Lototskyi \& Romanchuk, 2017).

Often, extreme physical exertion and mental stress exerted by personnel in the course of hostilities lead to a significant reduction in the combat capability of military personnel. This is most clearly manifested when the performance of fire missions deteriorates, the position and place of the performance of the combat mission on the battlefield is changed, and the speed and accuracy of actions when using weapons and military equipment are reduced (Klymovych, Olkhovyi \& Romanchuk, 2016; Lyzogub, 1999).

The degree of decrease in professionalism of military personnel in such conditions is determined by the size and nature of physical activity and stress, not sufficient professional training, low level of physical fitness, physical development, poor health and other factors. In some cases, the military-applied motor skills, the level of physical and psychological preparedness of the military personnel become crucial (Ovcharuk, 2016; Makarenko,1992).

In accordance with these requirements, we have developed and proposed a system of special physical training for servicemen and units of the Armed Forces of Ukraine in accordance with the specialization and direction of combat missions (Oderov et al, 2017; Sidorchenko, 2016; Makarenko, 1984).

\section{Materials and methods}

In order to solve certain problems, the following research methods were used:
- theoretical analysis, comparison, systematization and generalization of materials of scientific, methodological literature and guidelines on military-vocational training, definition of conceptual provisions that reveal the specifics of professionally directed physical training of cadets in the military army system;

- modeling - to study the properties and features of the subject of study, substantiation of the model of professionally directed physical training of military personnel of the Armed Forces of Ukraine;

- expert survey and method of expert evaluation - to find out the opinion of specialists in physical education on the quality of functioning of the system of physical training of cadets of higher educational establishments, to determine the importance of its components and ways of improvement (Oderov et al, 2017; Platonov, 2004).

As a result of the search for new methods of training military-applied motor skills, professionally directed physical training in the proposed combat system was implemented in educational institutions in three stages. In the first stage, it was introduced to the program of the discipline "Methods of Special Physical Training" for the students of the specialty "Physical Culture and Sports of the Military Academy. In the second stage of implementation (2019) - introduced as a discipline "Specialized physical training" for cadets of the 1st and 2nd faculties of the Military Academy (Odessa). The third stage (2020) introduced in the educational process of cadets of military educational institutions of Ukraine.

\section{Results}

The combat training system includes a complex of interconnected components (types) of professionally directed physical training that ensures the psychophysical readiness of servicemen to perform assigned tasks (Sidorchenko, 2018). The purpose of the introduction of a combat army system is to create a unified system of tacticalspecial and hand-to-hand training for the Special Forces of Ukraine, and especially for specialists of the special units, which have become the main types of this system.

The combat army system includes types of professionally directed physical and other types of training (Ovcharuk, 2018; Rolyuk, 2016): tactical-special (movement, choice of position, overcoming obstacles), mountain (assault, mountaineer), melee, applied shooting, tactical medicine, methodical training (fig. 1).

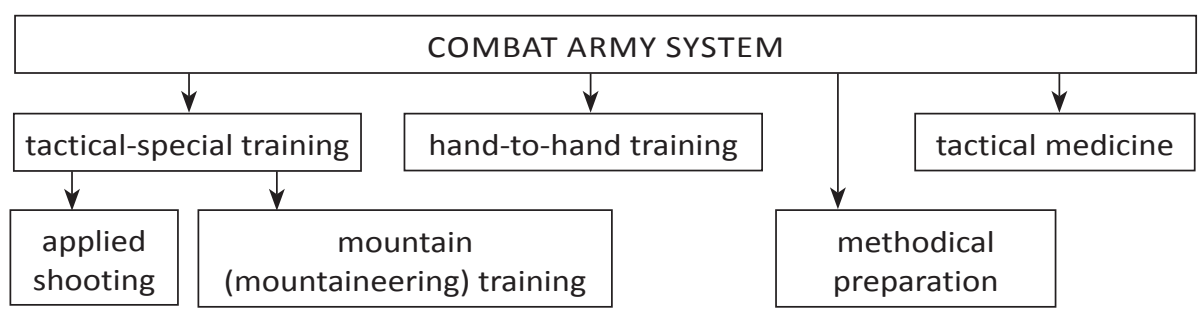

Fig. 1 Components of the Military Army System 
The subject of the Military Army System are:

- theoretical and methodological bases of physical training of troops;

- basics of medical and biological knowledge;

- methodical skills in all types of training.
Classes are based on a holistic concept, built on a single psychological basis, which can significantly improve the effectiveness of military and professional activity of personnel (fig. 2).

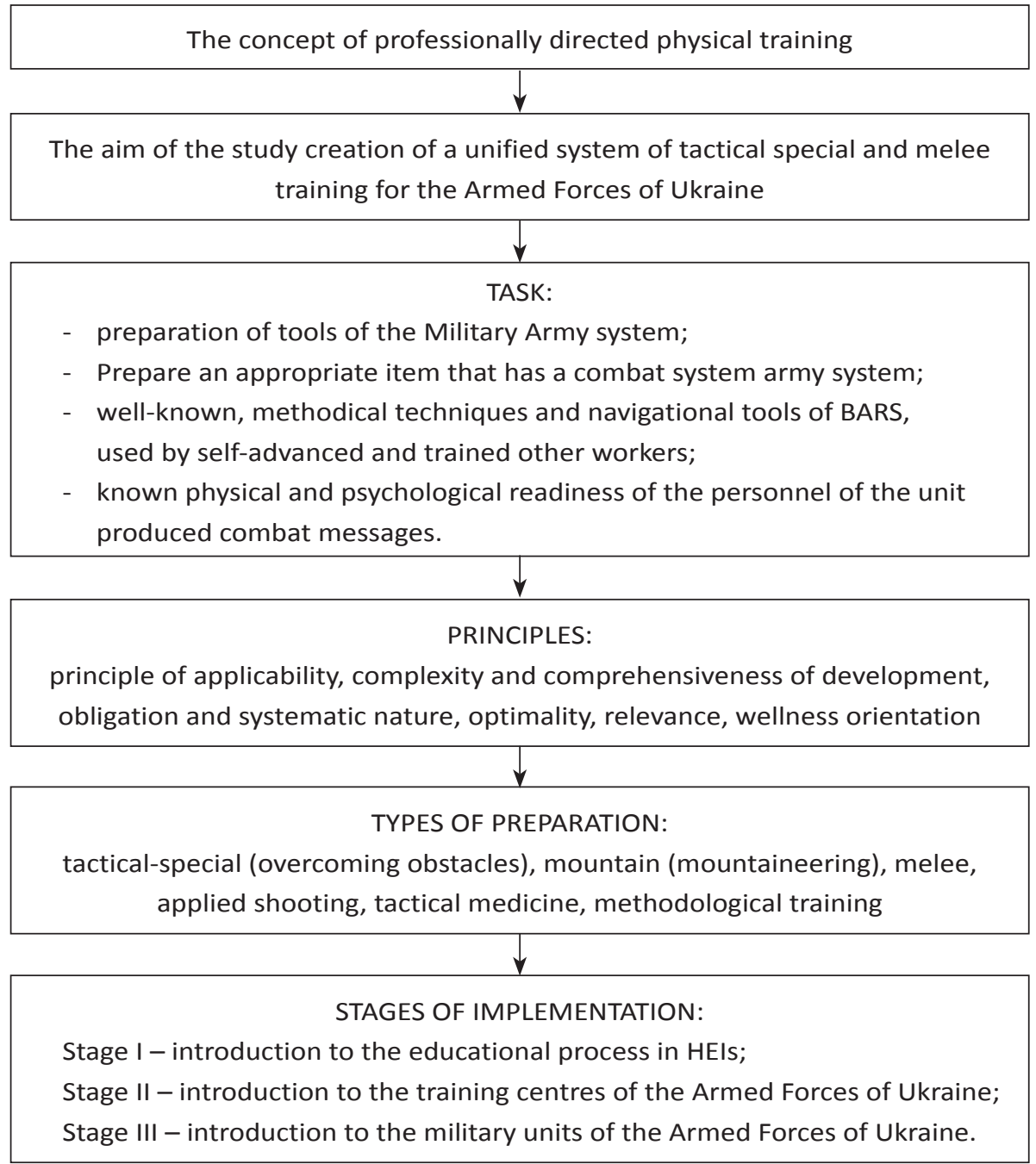

Fig. 2 The concept of professionally directed physical training in the Army's combat system

The main tasks of the Military Army System are:

- training of a specialist who knows the theoretical and methodological foundations of the system of physical training of troops, has the skills of planning, organizing and conducting training sessions on professionally directed physical training;

- training of a specialist of the appropriate level possessing the Military Army system;

- the formation of knowledge, methodical techniques and skills of the instructor of the Military Army System, capable of self-improvement and in a short time to train other servicemen;

- ensuring the physical and psychological readiness of the personnel of the unit to perform the combat task.

The principles of vocationally directed physical training in the Army's combat system have their specific focus.
Such principles are:

The principle of applicability: the use of specially selected physical exercises aimed at the development of physical and special qualities of military personnel, the formation and improvement of military-motor skills.

The principle of complexity and comprehensive development: the use of such tools and methods that would have a comprehensive impact on the personality of the warrior and ensure its comprehensive development.

Compulsory and systematic principle: Compulsory physical training for all categories of servicemen with regularity and in the forms specified in the Physical Training Guidelines (Oderov et al, 2020).

The principle of optimality: the development of military personnel's physical qualities, the formation of a set of motor skills, as well as their functional capabilities to 
a level that is sufficient for the successful performance of their military and professional functions.

Principle of conformity: the correspondence of physical training to the predicted features of military and professional activity.

The principle of health orientation: ensuring the promotion of health, reliable functional level of all organs and systems of the body of military personnel, biological and psychological resistance to the conditions of military service.

Professionally directed physical training is aimed at improving the functionality of the body, the development of special (resistance to overload, oscillation, spatial orientation) and basic physical qualities (agility, speed, strength, endurance) with simultaneous improvement of the ability to coordinate movement, manifestation various exercises, techniques and actions. Such training most fully corresponds to the tasks of developing the skills required in melee combat with the enemy against the background of physical and mental stress.

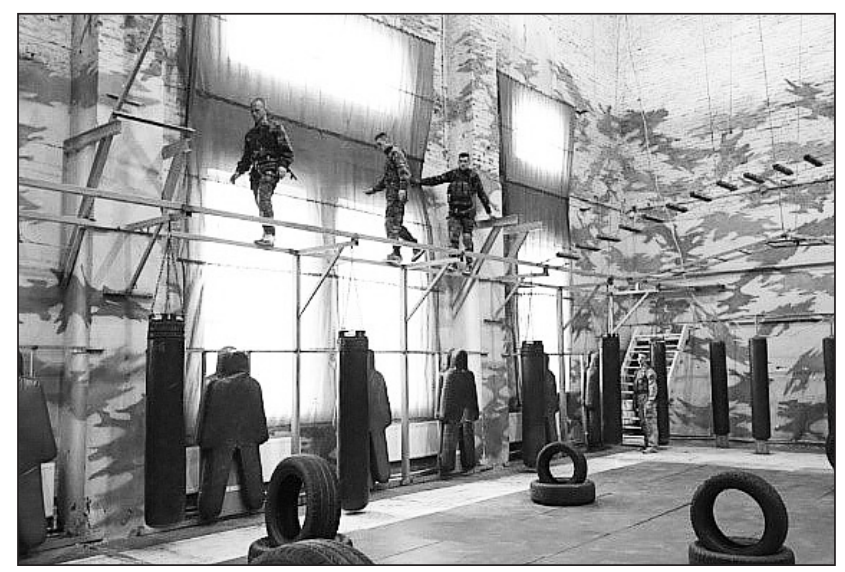

Tactical special training, as a type of specialized physical training, is that section of training of a soldier on the Military Army System, which provides various ways of movement without arms and with weapons in order to effectively use its properties, create favorable conditions to attack the enemy or protect against his aggressive actions (Ovcharuk \& Ivanov, 2016).

Training and training in tactical and special training are aimed at forming and improving skills in locomotion, rapid occupation of a favorable fire position and fire from small arms (without spending time aiming). Considerable attention is also given to learning to overcome various obstacles, to move at a height along a narrow, incl. not resistant supports, throwing cold weapons, special execution techniques and actions with and without weapons. All of the above is done on the basis of the constant psychological influence on the servicemen, the formation of the necessary moral and volitional qualities in them: perseverance, determination, courage, confidence in their abilities, etc (picture 1).

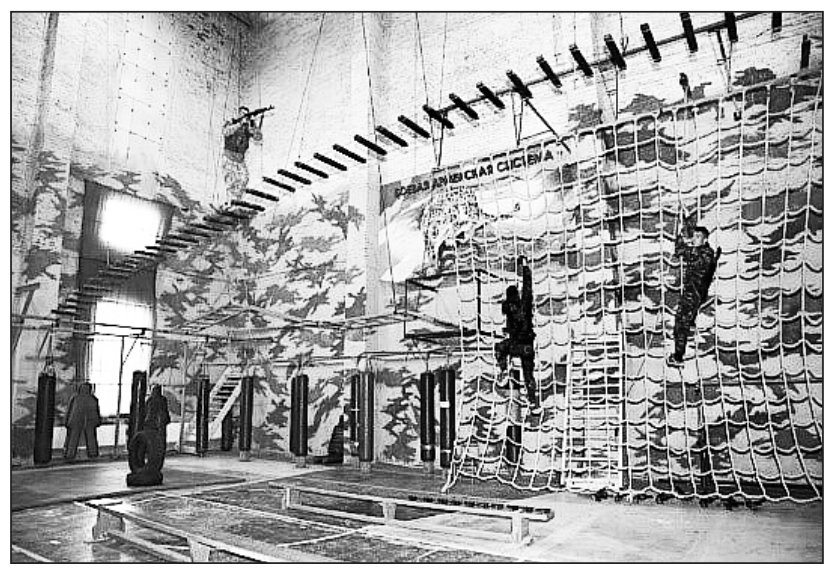

Picture 1 a, b Height movement on narrow and non-stable supports

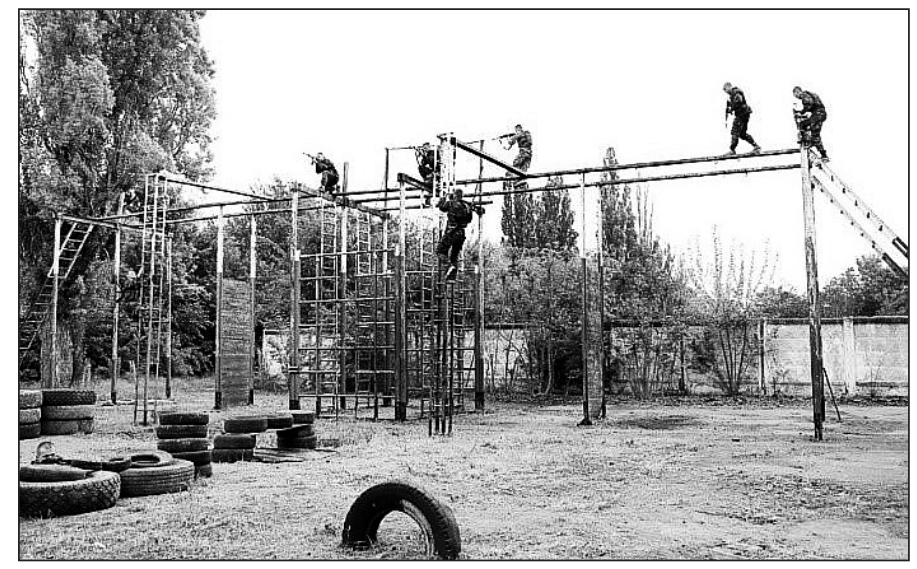

Picture 2 a, b Altitude travel on narrow supports and mountain preparation

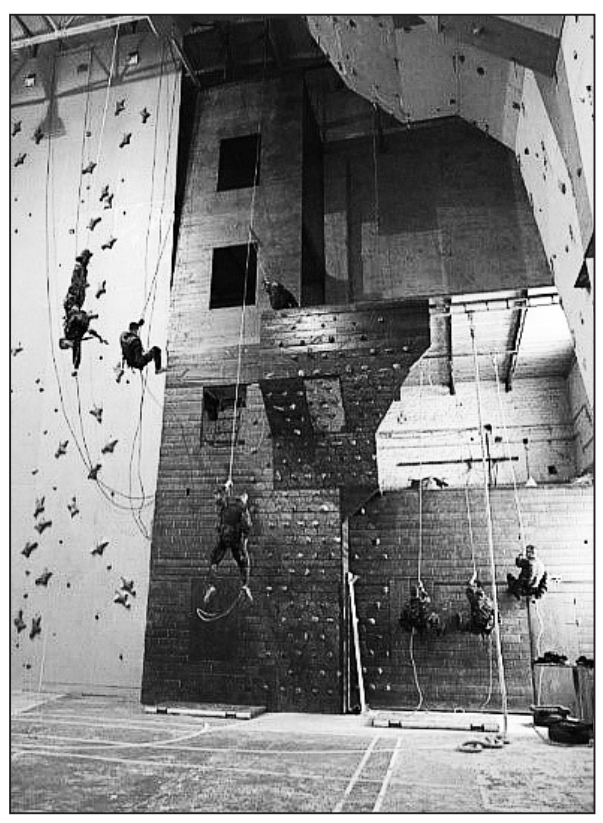


Classes are held on specially equipped obstacle course (stands) and on terrain, equipped with targets (Ovcharuk, 2017). Elements of mountain training - a set of techniques and methods that allow you to overcome obstacles in the mountains, perform combat tasks inside the objects, on the outside vertical of the house or in other inaccessible places with elements of mountaineering (picture 2).

Hand-to-hand training. Owning the techniques of melee combat gives the warriors the necessary motive stock of applied skills, creates a sense of confidence in their abilities, provides mental and psychological stability, and also forms a readiness for action in extreme situations related to the threat to their lives.

The peculiarity of the Combat Army system is its applied orientation, which has always distinguished combat schools of melee combat from other types of martial arts.

The purpose of combat is fundamentally different from sports. It is not to "outplay" an adversary by following certain rules and applying certain techniques, but to destroy it as soon as possible or to disable it, while maintaining the maximum of its own forces. Equally important is the psychological state of the fighter in the fight, in particular, the ability to suppress the instinct of self-preservation. Those involved in the military army system from the first days are trained in the specifics of "combat thinking", the formation of skills of constant readiness and the ability to instantly assess the situation with the selection of the best solution (Ovcharuk, Pavelko \& Belovodov, 2018).

Tactical medicine shapes the knowledge, skills and ability to provide effective assistance to yourself and a friend in combat.

Methodical training forms methodical techniques and the ability to teach staff using conventional means.

\section{Discussion}

The introduction into the training of military specialists, first of all military intelligence and special purpose of the Military Army system, is an extremely important and urgent task for the specialists of the physical training of the Armed Forces of Ukraine. Existing training methods for military personnel, in particular, for hand-to-hand combat, which have been used recently in the Armed Forces of Ukraine, have shown their unpromising nature, do not meet the requirements of intelligence training in modern conditions, and do not take into account the features of possible combat clashes (Ovcharuk et al., 2016).

The implementation of vocationally directed physical training in the Army's Armed Forces in the Armed Forces of Ukraine will take place in three stages:

Stage I - introduction of vocationally directed physical training into the educational process in higher military educational establishments;
Stage II - introduction to the training centers of the Armed Forces of Ukraine;

Stage III is the introduction into the military units of the Armed Forces of Ukraine.

The combat army system has a favorable orientation, always having to be ready for hand-to-hand combat with a numerically dominant enemy, and to keep the combat work at any time (in close space; or to disable it, while maintaining the maximum of its own forces. (Olkhovyi, 2013).

Prepare your own handmaids for the Army of God system, who can learn and refine the usual skills that emphasize their work. In addition, when conducting classes with this system of work of a personal worker used the general physical activity, as in the course of training introduced the basic physical labor.

Professionally directed physical training in the Army's combat system is constantly being improved, which sets it apart from other universal combat systems by a deeper study of fire fighting and destruction techniques. It must, first and foremost, ensure the proper training of the assault force, military intelligence and special forces units.

\section{Conclusions}

To sum up, conceptual use in the educational process of vocationally directed physical training in the Army's combat system involves the formation of military-applied motor skills, skills, physical and moral and volitional qualities to perform tasks on purpose.

In summary, we can conclude that BARS is a training system that fully provides quality training of servicemen to perform combat missions on purpose in modern conditions.

Our study revealed a positive effect of special physical training (BAS) on the level of development of physical qualities. Given the constant increase in requirements for the level of professional training of personnel of the Armed Forces of Ukraine, the need to ensure the physical readiness of servicemen for combat activities and physical training of units, physical education specialists should take measures to rationally use time during training sessions with personnel. In the future, our research is planned to focus on determining the impact of special physical training (BAS) on the level of development of professionally important (special) physical qualities of cadets of different specialties.

Conflict of interest. The authors declare no conflict of interest. 


\section{References}

1. Bondarchuk, I. Y. (1987). The influence of sports training on the functional capabilities of young runners. Theory and practice of physical culture, No. 5. 30-31.

2. Borilkevich, V. E. (1989). Physical performance in extreme conditions of muscular activity: author's abstract. dis. doct. biol. sciences. L. 47 p.

3. De Jesus, K. (2012). Kinemetic analysis of three water polo front crawl styles. Jornal of Sports Sciences. Vol. 30(7). 715-723.

4. Ivanova, E. M. (1992). Psychotechnology of studying a person in labour activity. Moscow: Publishing House of Moscow State University, 83-86.

5. Klymovych, V. (2020). Functional State of Military Personnel Engaged in Unarmed Combat. SportMont Journal, Vol. 18 (1). 99-101. DOI 10.26773/smj.200218.

6. Klymovych, V., Oderov, A., Romanchuk, S., Korchagin, M., Zolochevskyi, V., Fedak, S., Gura, I., Nebozhuk, O., Lashta, V., Romanchuk, V. and Lesko, O. (2020). Correlation of Physical Fitness and Professional Military Training of Servicemen. SportMont Journal, Vol. 18 (2). 79-82. DOI 10.26773/smj.200612.

7. Klymovych, V., Olkhovyi, O., \& Romanchuk, S. (2016). Adoption of youth's bodies to educational conditions in higher educational institutions. Journal of Physical Education and Sport, 3(1). 620-622.

8. Korchagin, M., Kurbakova, S. \& Olkhovyi, O.( 2017). Dependence of the success of professional activity of servicemen-operators on the level of psychophysiological qualities. Sports Gazette of Prydniprovia, 5(3). 65-68.

9. Krasova, I. (2012). Improvement of technical training in jump acrobatics through the impact on the sensorimotor coordination of athletes. Slobozhansky scientific and sports bulletin, 5(2). 27-32.

10. Lenart, D., Romanchuk, S., Andres, A., Lesko, O. \& Romanov, I. (2019). Optimization of the training and training process of military pentathlon fighters in conditions of insufficient educational and material support. Bulletin of Kamianets-Podilskyi Ivan Ohiienko National University. Physical Education, Sports and Human Health, Issue 13. 40-46.

11. Linets, M. M. (1994). Basics of the method of development of motor qualities. Lviv: Staffar.

12. Lototskyi, I. \& Romanchuk, S. (2017). Problems of preparation of military pentathlon in particular disciplines and ways of their solving. Youth Scientific Bulletin of Lesya Ukrainka Eastern European National University. Physical Education and Sport, Issue 27. 222-224.

13. Lyzogub, V. C. (1999). Formation of the strength of the nervous processes in human ontogenesis. Bulletin of the Taras Shevchenko Kyiv University, 7(5). 65-68.

14. Makarenko, L. P. (1992). Building sports training for highly-qualified swimmers: method. manual for students of the Higher School of Law. Physical education and sport. 50-52.

15. Makarenko, N. V. (1984). Latent period of sensory-motor reactions in persons with different functional mobility of the nervous system. Journal higher nervous, 34(6). 1041-1047.

16. Oderov, A., Klymovych, V., Korchagin, M., Olkhovy, O. \& Romanchuk, S. (2019). Optimization of the content of the physical training program of cadets-gunners. International Journal of Recent Scientific Research, Vol. 10, Issue, 07(A). 33340-33343. DOI: 10.24327/IJRSR.

17. Oderov, A., Klymovych, V., Romanchuk, S., Pankevich, Y., Pylypchak, I., Rolyuk, A., Lesko, O., Bilichenko, O., Dobrovolskyi, V., Vorontsov, O. (2020). Functional State of Military Personnel Engaged in Unarmed Combat. SportMont Journal, Vol. 18 (1). 99-101. DOI 10.26773/ smj.200218.

18. Oderov, A., Korchagin, M., Olkhovyi, O., Romanchuk, S. \& Klymovych, V. (2019). Motivation of forming students healthcare culture on principles of interdisciplinary integration. SportMont Journal, Vol. 17 (3). 79-83. DOI 10.26773/smj.191017.
19. Oderov, A., Romanchuk, S., Fedak, S., Kuznetsov, M., Petruk, A., DunetsLesko, A., Lesko, O., Olkhovyi O. (2017). Innovative approaches for evaluating physical fitness of servicemen in the system of professional training. Journal of Physical Education and Sport, Vol. 17 (3). 23-27.

20. Olkhovyi, O. (2013). Theoretical and methodological foundations of the system of physical training of cadets of higher military educational establishments: abstract of dissertation work. 40 p.

21. Ostapenko, Y. A. (2014). Professional-meaning psychophysiological qualities of the information-logical group of specialties. Pedagogics, psychology and medical-biological problems of physical education and sport, 4(6). 34-39.

22. Ovcharuk, I. \& Ivanov, S (2016). Modern aspects of the military training of military personnel of the Armed Forces of Ukraine in the combat army system. Materials of reports of participants of scientific and practical seminar. 80-82.

23. Ovcharuk, I. (2016). Basic provisions and elements of the main types of training in the Army's combat system. Military Academy, 1. 102-103.

24. Ovcharuk, I. (2017). Study the effectiveness of the program on the Army's combat system. National Academy of Land Forces. 149-150.

25. Ovcharuk, I. (2018). The military system is a complex component in the training of military personnel. Ivan Chernyakhovsky National University of Defense of Ukraine. 78-80.

26. Ovcharuk, I. et al. (2016). Guidelines on the use of elements of the Army's combat system in training in fire, tactical, physical training and tactical medicine. Military Academy. 117-118.

27. Ovcharuk, I. \& Belovodov I. (2018). Organizational and methodological issues of the introduction of the Military Army system in the system of physical training of troops. Modern tendencies and prospects of development of military-applied orientation of special physical training and diving training. 61-62.

28. Platonov V. (2004). The system of training athletes in Olympic sports. General theory and its practical applications. Olympic literature. 806-808.

29. Platonov, V. (2013). Forcing the long-term training of athletes and Youth Olympic Games. Science in Olympic Sports, 2. 36-37.

30. Rolyuk, O. (2016). Improvement of physical training of military personnel by means of applied sports. Scientific journal. Scientific and pedagogical problems of physical culture / physical culture and sports, No 1 (68). 74-77.

31. Romanchuk, S. (2020). The impact of mass sports work in educational institution on the formation of cadets' value attitude towards the physical education. SportMont Journal, Vol. 18 (1). 81-86. DOI 10.26773/smj.200214.

32. Shinkaruk, A. (2013). Justification of an integrated approach to the development of a selection program in cyclic sports. Theory and methodology of physical education and sports, 1. 24-25.

33. Sidorchenko, K. (2018). Some features of the developed system of vocational and physical training. Scientific bases of functioning of system of methodical work in the Military Academy and ways of increasing its effectiveness. 121-122.

34. Tovstonoh, A. (2010). Individualization of training athletes as the basis for achieving a high sports result. Young Sports Science of Ukraine, 14(1). 322-327.

35. Varakin, A. P. Special workability. The development of physical qualities in modern pentathlon. Moskow: FiS, 1983.

36. Klymovych, V., Olkhovyi, O. \& Romanchuk, S. (2016). Adoption of youth's bodies to educational conditions in higher educational institutions. Journal of Physical Education and Sport (JPES), 3(1). 620-622. 